\title{
Application of Weighted Fuzzy Time Series Model to Forecast Trans Jogja's Passengers
}

\author{
Kurrotul A'yun ${ }^{1 *}$, Agus Maman Abadi², Fitriana Yuli Saptaningtyas ${ }^{2}$ \\ ${ }_{1}^{1}$ Department of Mathematics, Faculty of Mathematics and Natural Science, State University of Yogyakarta, \\ Indonesia. \\ ${ }^{2}$ Department of Mathematics Education, Faculty of Mathematics and Natural Science, State University of \\ Yogyakarta, Indonesia. \\ * Corresponding author. Tel.: +6289685456983; email: kurrotulayun29@gmail.com \\ Manuscript submitted September 12, 2014; accepted January 30, 2015. \\ doi: 10.17706/ijapm.2015.5.2.76-85
}

\begin{abstract}
Trans Jogja is a public transportation in Yogyakarta which is operated by Dishubkominfo DIY. It is one of the ways to overcome transportation problems especially traffic jams. The total number of the buses until now reaches to 54. In fact, it does not significantly overcome the traffic jam problem yet. Dishubkominfo DIY always makes some efforts to improve the Trans Jogja management. One of them is by giving good services to the passengers. So, it is important to predict the amount of the passengers of Trans Jogja. This forecast uses the data from July $1^{\text {st }} 2014$ - September $29^{\text {th }} 2014$. This forecast is based on Weighted Fuzzy Time Series (WFTS). To forecast using WFTS, there are some important steps. There are defining the universe of discourse $U$, defining the fuzzy sets, establishing fuzzy logical relationship, grouping, forecasting, defuzzification, assigning weights and the last is calculating the final forecast values. The data of passengers is not stationer. It must be stationered first by differencing the data. From the forecasting result, MAPE and MSE of testing data are larger than MAPE and MSE of training data. So, WFTS can be used to predict Trans Jogja passenger in the following time.
\end{abstract}

Key words: Forecasting, trans Jogja's passengers, weighted fuzzy time series.

\section{Introduction}

Yogyakarta is one of the populous cities in Indonesia [1]. Traffic jam happens especially at the rush hours. Operating Trans Jogja bus is one of strategies that have been made [2] to solve traffic jams. Trans Jogja bus is operated since 2008 and it has been alternative solution to provide public transport-based on "buy the service". The number of the buses is 54 buses with 112 shelters. A good management of buses of Trans Jogja makes them interesting. To improve the management, it is needed to know the number of passengers. Thus, a research to predict the number of Trans Jogja passengers is significant to be conducted.

Some researchers have conducted researches which predict the buses passengers. One of them is Hidayat [3] with his research about the method of Adaptive Neuro Fuzzy Inference System and When-xia [4] using regression analysis method.

The fuzzy time series method is a dynamic process that uses linguistic values as observations. The research on fuzzy system that uses time series data was first conducted by Song [5]-[7] to predict the number of enrollments in a university. Other research conducted by Nurhayadi [8] is to predict the register at the Albama University. Then, Shah [9] applied fuzzy time series to predict the gross domestic capital in 
India. One more researcher, Abadi [10], constructed fuzzy time series that combines the lookup tables and value decomposition method for predicting inflation rate.

Chen [11], in the year 1996 developed Song method which is further developed by Yu [12] in 2005. Again, Song method is developed by Lee [13] talking about the seasonal data and by Suhartono [14], [15] about forecasting seasonal and trend data. Finally, the study by Suhartono is applied to forecast tourist arrivals.

In fact, Lee's research [16] weighted fuzzy time series method has better accuracy than Chen's [11], Yu's [12], and Cheng's [17] method. Thus, in this paper, the writer used the Lee's method to predict the passengers of Trans Jogja bus. Since Lee [16] has many orders, the writer merely use the first one which is about weighted fuzzy time series model with data time variant. The data obtained are in the form of daily data of Trans Jogja's passengers. Differencing data to get stationary data is important since the data are not stationer. After acquiring the results of forecasting, the writer calculated the value of MAPE (Mean Absolute Percentage Error) and MSE (Mean Square Error) of fuzzy time series method and weighted fuzzy time series method [16].

\section{Forecasting with Fuzzy Time Series}

Fuzzy time series (FTS) is the development of a fuzzy system using time series data. Linguistic variables that used in this research are the data in the previous period which is mapped in to the data in the next period.

Definition 2.1. [11] Let $U$ be universe of discourse, $U=\left\{u_{1}, u_{2}, \ldots, u_{n 1}\right\}$. A fuzzy set $A$ of $U$ is defined by

$$
A=\left\{\frac{f_{A}\left(u_{1}\right)}{u_{1}}+\frac{f_{A}\left(u_{2}\right)}{u_{2}}+\ldots+\frac{f_{A}\left(u_{n}\right)}{u_{n}}\right\}
$$

where $f_{A}$ is the membership function of $A, f_{A}: U \rightarrow[0,1]$, and $f_{A}\left(u_{1}\right)$ indicates the grade of membership of $u_{1}$ in $A$, where $f_{A}\left(u_{1}\right) \in[0,1]$ and $1 \leq i \leq n$.

Definition 2.2. [5] Let $Y(t)(t=\ldots, 0,1,2, \ldots)$, a subset of $R$, be the universe of discourse on which fuzzy set $f_{i}(t)(i=1,2, \ldots)$ are defined and $F(t)$ be a collection of $f_{i}(t)(i=1,2, \ldots)$. Then, $F(t)$ is called a fuzzy time series on $Y(t)(t=\ldots, 0,1,2, \ldots)$.

Definition 2.3. [11] If there exists a fuzzy relationship $R(t-1, t)$, such that $F(t)=F(t-1) \circ R(t-1, t)$, where $\circ$ is an arithmetic operator, then $F(t)$ is said to be caused by $F(t-1)$. The relationship between $F(t)$ and $F(t-1)$ can be denoted by $F(t-1) \rightarrow F(t)$.

Definition 2.4. [11] Let $F(t)$ be a fuzzy time series. If for any time, $F(t)=F(t-1)$ and $F(t)$ only has finite elements, then $F(t)$ is called a time-invariant fuzzy time series. Otherwise, it is called a time-variant fuzzy time series.

Based on Definition 2.4., in this forecasting, the data must be stationary data.

Definition 2.5. [11] Suppose $F(t-1)=A_{i}$ and $F(t)=A_{j}$, a fuzzy logical relationship can be defined as

$$
A_{i} \rightarrow A_{j}
$$

where $A_{i}$ and $A_{j}$ are called the left-hand side (LHS) and right-hand side (RHS) the fuzzy logical 
relationship, respectively.

The steps to forecast with fuzzy time series [11] are given as follows:

Step 1. Define the universe of discourse U.

Step 2. Divide the universal of discourse $U$ with the same interval.

Step 3. Define fuzzy set on a universal discourse called U.

Step 4. Determine the fuzzy logical relationship.

Step 5. Establish group the fuzzy logical relationship.

Step 6. Forecast. Let $F(t-1)=A_{i}$,

Case 1: If the fuzzy logical relationship of $A_{i}$ is empty; $A_{i} \rightarrow \varnothing$, then $F(t)$, forecast value, is equal to $A_{i}$.

Case 2: There is only one fuzzy logical relationship in the fuzzy logical relationship sequence. If $A_{i} \rightarrow A_{j}$, then $F(t)$, forecast value, is equal to $A_{j}$.

Case 3: If $A_{i} \rightarrow A_{j_{1}}, A_{j_{2}}, \ldots, A_{j_{k}}$, then $F(t)$, forecast value, is equal to $A_{j_{1}}, A_{j_{2}}, \ldots, A_{j_{k}}$.

Step 7. Defuzzification. If the forecast of $F(t)$ is $A_{j_{1}}, A_{j_{2}}, \ldots, A_{j_{k}}$, the defuzzified result is equal to the arithmetic average of the midpoints of $A_{j_{1}}, A_{j_{2}}, \ldots, A_{j_{k}}$.

\section{Forecasting with Weighted Fuzzy Time Series}

Different with forecasting using fuzzy time series, forecasting using weighted fuzzy time series adds weight after defuzzification step. The steps of forecasting using Weighted Fuzzy Time Series (WFTS) method [16] are given as follows:

Step 1. Define the universe of discourse U.

Step 2. Divide the universal of discourse U with the same interval.

Step 3. Define fuzzy set on a universal discourse called U.

Step 4. Determine the fuzzy logical relationship.

Step 5. Establish group the fuzzy logical relationship.

Step 6. Forecast, with fuzzy time series method.

\section{Step 7. Defuzzification.}

Step 8. Assign weights. Suppose the forecast of $F(t)$ is $A_{j 1}, A_{j 2}, \ldots, A_{j k}$. The corresponding weight for $A_{j 1}, A_{j 2}, \ldots, A_{j k}$, say $w_{1}^{\prime}, w_{2}^{\prime}, \ldots, w_{k}^{\prime}$ are

$$
w_{i}^{\prime}=\frac{w_{i}}{\sum_{h=1}^{k} w_{i}}
$$

where $w_{1}=1$ and $w_{i}=c^{i-1}$ for $c \geq 1$ and $2 \leq i \leq k$. Changed to weight matrix form, equation (3) will be

$$
w(t)=\left[\frac{w_{1}}{\sum_{h=1}^{k} w_{i}}, \frac{w_{2}}{\sum_{h=1}^{k} w_{i}}, \ldots, \frac{w_{k}}{\sum_{h=1}^{k} w_{i}}\right]
$$




$$
w(t)=\left[\frac{1}{\sum_{h=1}^{k} w_{i}}, \frac{c}{\sum_{h=1}^{k} w_{i}}, \frac{c^{2}}{\sum_{h=1}^{k} w_{i}}, \ldots, \frac{c^{k-1}}{\sum_{h=1}^{k} w_{i}}\right]
$$

where $w_{k}$ is the corresponding weight for $A_{i j}$.

Step 9. Calculate the final forecast values. The final forecast is equal to the product of the defuzzified matrix and the transpose of the weight matrix:

$$
\hat{F}(t)=M(t) \times W(t)^{T}=\left[m_{j_{1}}, m_{j_{2}}, \ldots, m_{j_{k}}\right] \times\left[\frac{1}{\sum_{h=1}^{k} w_{i}}, \frac{c}{\sum_{h=1}^{k} w_{i}}, \ldots, \frac{c^{k-1}}{\sum_{h=1}^{k} w_{i}}\right]^{T}
$$

where $x$ is the matrix product operator.

\section{Application on Forecasting The Trans Jogja's Passengers}

\subsection{Determining Stationary Data}

Before predicting the number of Trans Jogja's passengers using the Weighted Fuzzy Time series, the data must be stationered. The data [18] that used in this research is data of Trans Jogja's passengers count based from the ticket sales in the period of 1 July2014 to 29 September2014. The number of data is 91 data taken from daily data of Trans Jogja passengers. The data are divided into 72 training and 19 testing data. Checkingdata is done by using Minitab 16,by ploting data using Autocorelation Function (ACF). Here is the plot of the data of passengers, followed by ACF plot.

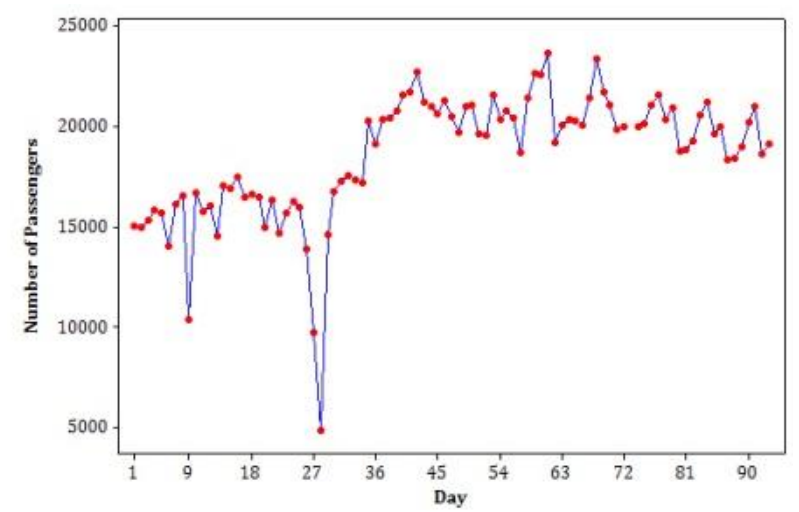

(a)

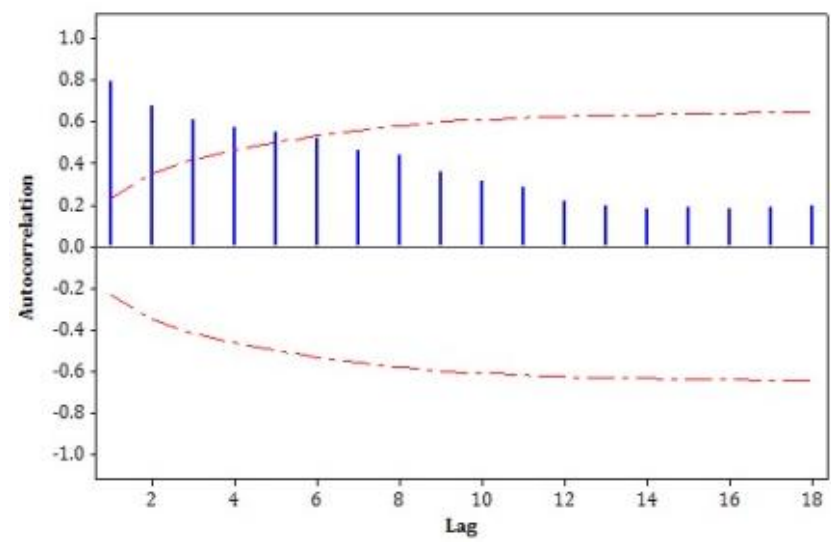

(b) 


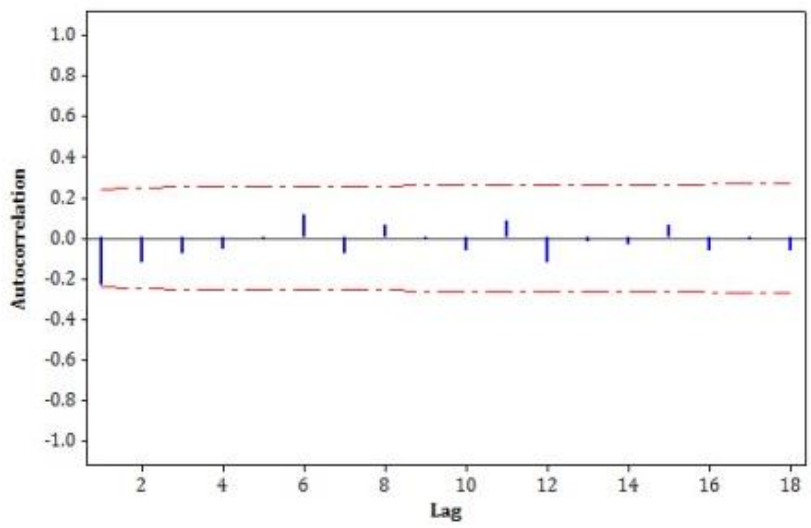

(c)

Fig. 1. (a) The data plot of Trans Jogja's passengers; (b) The ACF of original data; (c) The ACF plot of resulting data after differentiation.

Fig. 1 (b) displays that there are some lags that come out of the significance line.It means that the data are not stationary. Thus, to obtain stationary data, diferencing the data is a must. In this paper, differencing the data is conducted using Minitab16 or manually by [19]:

$$
P_{t+1}=Y_{t+1}-Y_{t}
$$

We need to plot the ACF to see the data of Trans Jogja's passengers after the differencing process. Fig. 1(c) shows that there is no lag came out of the significance line. It means that the data has been stationary with one differentiation. Furthermore, by using resulting data after differentiation that has already stationared (hereinafter called stationary data), the passengers of Trans Jogja can be forecasted by using the Weighted Fuzzy Time Series (WFTS).

\subsection{Forecasting Trans Jogja's Passengers Using Weighted Fuzzy Time Series}

The forecasting process of Trans Jogja's passengers with stationary data that has been obtained is conducted by the following steps:

Step 1. Define the universal discourse U.

Based on obtained stationary data, the smallest datum is -6106 and the largest datum 9772 . So, the universal of discourse for this data is $U=\left[\begin{array}{ll}-7250 & 10250\end{array}\right]$.

Step 2. Divide the universal of discourse $U$ with the same interval.

To simplify universal set of partitions into particular parts, the data is changed to the form of chart. The chart is represented in Fig 2(a).Based on the chart, the universal of discourse $U$ is partitioned into 7 sections with long intervals (2500) of each section. The sections are: $u_{1}=\left[\begin{array}{lll}-7250 & -4750\end{array}\right]$, $u_{3}=\left[\begin{array}{ll}-2250 & 250\end{array}\right] u_{3}=\left[\begin{array}{ll}-2250 & 250\end{array}\right], u_{4}=\left[\begin{array}{ll}250 & 2750\end{array}\right], u_{5}=\left[\begin{array}{ll}2750 & 5250\end{array}\right], u_{6}=\left[\begin{array}{lll}5250 & 7750\end{array}\right]$, and $u_{7}=\left[\begin{array}{ll}7750 & 10250\end{array}\right]$.

Step 3. Define fuzzy set on a universal of discourse called $U$.

The next step is to define the intervals into a fuzzy set. In this study, the writer used 5 linguistic variables: $A_{1}=$ very very little, $A_{2}=$ very little, $A_{3}=$ a little $A_{4}=$ moderate, $A_{5}=$ much, $A_{6}=$ very much, and $A_{7}=$ very very much.Then, the writer defined fuzzy sets $A_{1}, A_{2}, A_{3}, A_{4}, A_{5}, A_{6}$ and $A_{7}$ on the universal of discourse $\mathrm{U}$ : 


$$
\begin{aligned}
& A_{1}=\frac{1}{u_{1}}+\frac{0.5}{u_{2}}+\frac{0}{u_{3}}+\frac{0}{u_{4}}+\frac{0}{u_{5}}+\frac{0}{u_{6}}+\frac{0}{u_{7}}, \\
& A_{2}=\frac{0.5}{u_{1}}+\frac{1}{u_{2}}+\frac{0.5}{u_{3}}+\frac{0}{u_{4}}+\frac{0}{u_{5}}+\frac{0}{u_{6}}+\frac{0}{u_{7}} \\
& A_{3}=\frac{0}{u_{1}}+\frac{0.5}{u_{2}}+\frac{1}{u_{3}}+\frac{0.5}{u_{4}}+\frac{0}{u_{5}}+\frac{0}{u_{6}}+\frac{0}{u_{7}} \\
& A_{4}=\frac{0}{u_{1}}+\frac{0}{u_{2}}+\frac{0.5}{u_{3}}+\frac{1}{u_{4}}+\frac{0.5}{u_{5}}+\frac{0}{u_{6}}+\frac{0}{u_{7}} \\
& A_{5}=\frac{0}{u_{1}}+\frac{0}{u_{2}}+\frac{0}{u_{3}}+\frac{0.5}{u_{4}}+\frac{1}{u_{5}}+\frac{0.5}{u_{6}}+\frac{0}{u_{7}} \\
& A_{6}=\frac{0}{u_{1}}+\frac{0}{u_{2}}+\frac{0}{u_{3}}+\frac{0}{u_{4}}+\frac{0.5}{u_{5}}+\frac{1}{u_{6}}+\frac{0.5}{u_{7}}, \\
& A_{7}=\frac{0}{u_{1}}+\frac{0}{u_{2}}+\frac{0}{u_{3}}+\frac{0}{u_{4}}+\frac{0}{u_{5}}+\frac{0.5}{u_{6}}+\frac{1}{u_{7}} .
\end{aligned}
$$

From the fuzzy sets, it is known that this study uses a triangular membership functions.

Step 4. Determine the fuzzy logical relationship.

Fuzzy logical relationship (FLR) is used in forecasting established by partitioning the universal of discourse and defining of fuzzy sets. Establishment of the FLR conducted based on fuzzy logic: if $P_{t}=A_{i}$ then $\hat{P}_{i}=\hat{A}_{i+1}$.

Step 5. Group or establish the fuzzy logical relationship.

In this step, the FLR on step 4 is grouped for each fuzzy set. The result of grouping fuzzy logic relationship is shown on Table 1.

Table 1. Group of Fuzzy Logical Relationship (FLR)

\begin{tabular}{llcc}
\hline \hline Group & LHS & RHS & $\begin{array}{c}\text { Number } \\
\text { of RHS }\end{array}$ \\
\hline 1 & $\mathrm{~A}_{1}$ & $\mathrm{~A}_{6}, \mathrm{~A}_{7}$ & 2 \\
2 & $\mathrm{~A}_{2}$ & $\mathrm{~A}_{1}, \mathrm{~A}_{4}$ & 2 \\
3 & $\mathrm{~A}_{3}$ & $\mathrm{~A}_{4}, \mathrm{~A}_{3}, \mathrm{~A}_{4}, \mathrm{~A}_{4}, \mathrm{~A}_{4}, \mathrm{~A}_{4}, \mathrm{~A}_{3}, \mathrm{~A}_{3}, \mathrm{~A}_{3}, \mathrm{~A}_{4}, \mathrm{~A}_{4}, \mathrm{~A}_{3}, \mathrm{~A}_{2}, \mathrm{~A}_{3}, \mathrm{~A}_{5}, \mathrm{~A}_{4}, \mathrm{~A}_{4}, \mathrm{~A}_{4}, \mathrm{~A}_{3}, \mathrm{~A}_{3}, \mathrm{~A}_{4}, \mathrm{~A}_{3}, \mathrm{~A}_{4}, \mathrm{~A}_{3}, \mathrm{~A}_{3}, \mathrm{~A}_{4}$, & 35 \\
4 & \multicolumn{2}{c}{$\mathrm{A}_{4}, \mathrm{~A}_{4}, \mathrm{~A}_{4}, \mathrm{~A}_{3}, \mathrm{~A}_{4}, \mathrm{~A}_{3}, \mathrm{~A}_{3}, \mathrm{~A}_{3}$} \\
5 & $\mathrm{~A}_{4}$ & $\mathrm{~A}_{4}, \mathrm{~A}_{3}, \mathrm{~A}_{4}, \mathrm{~A}_{1}, \mathrm{~A}_{3}, \mathrm{~A}_{3}, \mathrm{~A}_{3}, \mathrm{~A}_{3}, \mathrm{~A}_{4}, \mathrm{~A}_{3}, \mathrm{~A}_{4}, \mathrm{~A}_{4}, \mathrm{~A}_{3}, \mathrm{~A}_{3}, \mathrm{~A}_{4}, \mathrm{~A}_{3}, \mathrm{~A}_{3}, \mathrm{~A}_{3}, \mathrm{~A}_{3}, \mathrm{~A}_{3}, \mathrm{~A}_{3}, \mathrm{~A}_{4}, \mathrm{~A}_{3}, \mathrm{~A}_{2}, \mathrm{~A}_{4}, \mathrm{~A}_{3}$, & 28 \\
5 & $\mathrm{~A}_{5}$ & $\mathrm{~A}_{3}$ & 1 \\
7 & $\mathrm{~A}_{6}$ & $\mathrm{~A}_{3}$ & 1 \\
\hline \hline
\end{tabular}

Step 6-7. Forecast and Defuzzification. In this step, the first thing to do is determining the midpoint of each interval fuzzy sets. There are $m_{1}=-6000, m_{2}=-3500, m_{3}=-1000, m_{4}=1500, m_{5}=4000$, $m_{6}=6500$, dan $m_{7}=9000$.

Step 8-9. Assigning weights and calculating the value of forecasting result.After acquiring the midpoint of the interval fuzzy sets, the next step is defuzzifying. The Table 2 shown the defuzzification results of each linguistic variable with $c=2$. 
Table 2. The Value of Forecast Result

\begin{tabular}{|c|c|}
\hline $\begin{array}{l}\text { Fuzzy } \\
\text { Sets }\end{array}$ & Computation \\
\hline $\mathrm{A}_{1}$ & $\hat{A}_{t+1}=\frac{m_{6}+2 m_{7}}{1+2}=\frac{6500+2(9000)}{3}=8166.667=8166$ \\
\hline $\mathrm{A}_{2}$ & $\hat{A}_{t+1}=\frac{m_{1}+2 m_{4}}{1+2}=\frac{-6000+2(1500)}{3}=-1000$ \\
\hline $\mathrm{A}_{3}$ & $\begin{array}{c}\hat{A}_{t+1}=\frac{m_{4}+2 m_{3}+4 m_{4}+\cdots+2^{34} m_{3}}{1+2+4+\cdots+2^{34}}=\frac{1500+2(-1000)+4(1500)+\cdots+2^{34}(10000)}{34359738367} \\
=\frac{-2.67123 E+13}{34359738367}=-777.4316699=-777\end{array}$ \\
\hline $\mathrm{A}_{4}$ & $\begin{array}{c}\hat{A}_{t+1}=\frac{m_{4}+2 m_{3}+4 m_{4}+\cdots+2^{27} m_{3}}{1+2+4+\cdots+2^{27}}=\frac{1500+2(-1000)+4(1500)+\cdots+2^{27}(10000)}{268435455} \\
=\frac{-74399722500}{268435455}=-277.1605655=-277\end{array}$ \\
\hline $\mathrm{A}_{5}$ & $\hat{A}_{t+1}=m_{3}=-1000$ \\
\hline $\mathrm{A}_{6}$ & $\hat{A}_{t+1}=m_{3}=-1000$ \\
\hline $\mathrm{A}_{7}$ & $\hat{A}_{t+1}=m_{4}=1500$ \\
\hline
\end{tabular}

\subsection{Return of the Differencing Data}

After acquiring the value of forecasting results, the result data from the stationary data is returned to the original data to obtain the results of forecasting. Based on the equation (7), the return of the differencing data to the stationary data is obtained by equation

$$
\hat{Y}_{t+1}=\hat{P}_{t+1}+Y_{t}
$$

The forecasting result that are needed as training data are shown on Table 3 and Table 4 show the testing data. The data forecasting result with weighted fuzzy time series method is still in the form of differencing data. Table 3 shows that data from the forecasting resultinforms the number passengers on day- $t$.

Table 3. The Forecasting Result of Training Data

\begin{tabular}{|c|c|c|c|c|c|c|c|c|c|c|c|c|c|c|c|}
\hline \multirow{2}{*}{ Day } & \multirow{2}{*}{$Y_{t}$} & \multicolumn{2}{|c|}{ Result } & \multirow{2}{*}{ Day } & \multirow{2}{*}{$Y_{t}$} & \multicolumn{2}{|c|}{ Result } & \multirow{2}{*}{ Day } & \multirow{2}{*}{$Y_{t}$} & \multicolumn{2}{|c|}{ Result } & \multirow{2}{*}{ Day } & \multirow{2}{*}{$Y_{t}$} & \multicolumn{2}{|c|}{ Result } \\
\hline & & $\hat{P}_{t}$ & $\hat{Y}_{t}$ & & & $\hat{P}_{t}$ & $\hat{Y}_{t}$ & & & $\hat{P}_{t}$ & $\hat{Y}_{t}$ & & & $\hat{P}_{t}$ & $\hat{Y}_{t}$ \\
\hline 1 & 15015 & & & 25 & 15987 & -777 & 15477 & 37 & 20357 & -277 & 18874 & 55 & 20761 & -277 & 20067 \\
\hline 2 & 14978 & & & & 3862 & -777 & 15210 & & 0450 & -777 & 80 & & 9 & -777 & 9984 \\
\hline 3 & 15346 & -277 & 14701 & 27 & 9759 & -1000 & 12862 & 39 & 20813 & -277 & 20173 & 57 & 18710 & -777 & 19642 \\
\hline 4 & 15825 & -277 & 15069 & 28 & 4834 & 8166 & 17925 & 40 & 21602 & -277 & 20536 & 58 & 214 & -277 & 18433 \\
\hline 5 & 15707 & -777 & 15048 & 29 & 14606 & 1500 & 6334 & 41 & 21727 & -777 & 20825 & 59 & 22637 & -277 & 21178 \\
\hline 6 & 14046 & -777 & 14930 & 30 & 16776 & -277 & 14329 & 42 & 22709 & -277 & 21450 & 60 & 22590 & -777 & 21860 \\
\hline 7 & 16108 & -277 & 13769 & 31 & 17297 & -277 & 16499 & 43 & 21225 & -777 & 21932 & 61 & & -277 & 22313 \\
\hline 8 & 16514 & -277 & 158 & 32 & 175 & -277 & 17020 & 44 & $20 \mathrm{c}$ & -777 & 20448 & & & -1000 & 22653 \\
\hline 9 & 104 & & & 33 & & -777 & 16771 & 4 & 20 & -777 & & & 20 & -277 & 18918 \\
\hline 10 & 16670 & -1000 & & 34 & 172 & -77 & 16556 & 4 & 21294 & -277 & 203 & & 20 & -277 & 19760 \\
\hline 11 & 15754 & -777 & 158 & 35 & 20297 & -1000 & 16 & 47 & 20476 & -777 & 20517 & 6 & 20 & -777 & 19569 \\
\hline 12 & 16070 & -277 & 15 & 36 & 19151 & -777 & 19520 & 48 & 19 & -777 & 19 & 66 & 20 & -777 & 19485 \\
\hline 13 & 14568 & -777 & 15293 & 19 & 16496 & -777 & 15853 & 49 & 21001 & -277 & 19414 & 67 & 21452 & -277 & 19778 \\
\hline 14 & 17050 & -277 & 14291 & 20 & 14974 & -777 & 15719 & 50 & 21099 & -777 & 20224 & 68 & 23348 & -277 & 21175 \\
\hline 15 & 16920 & -777 & 16273 & 21 & 16336 & -277 & 14697 & 51 & 19662 & -777 & 20322 & 69 & 21718 & -777 & 22571 \\
\hline 16 & 17459 & -277 & 16643 & 22 & 14654 & -777 & 15559 & 52 & 19576 & -777 & 18885 & 70 & 21086 & -777 & 20941 \\
\hline 17 & 16500 & -777 & 16682 & 23 & 15700 & -277 & 14377 & 53 & 21583 & -277 & 19299 & 71 & 19820 & -777 & 20309 \\
\hline 18 & 16630 & -777 & 15723 & 24 & 16254 & -277 & 15423 & 54 & 20344 & -777 & 20806 & 72 & 19991 & -777 & 19043 \\
\hline
\end{tabular}


Similar to Table 3, Table 4 shows that the data from the forecasting results are changed to be the data of forecasting passenger, but in the form of testingdata. Testing data in Table 4 are not used to build the model (the rules of fuzzy relationship).

Table 4. The Forecasting Result of Testing Data

\begin{tabular}{|c|c|c|c|c|c|c|c|c|c|c|c|c|c|c|c|}
\hline \multirow[b]{2}{*}{ Day } & \multirow[b]{2}{*}{$Y_{t}$} & \multicolumn{2}{|c|}{ "Result } & \multirow[b]{2}{*}{ Day } & \multirow[b]{2}{*}{$Y_{t}$} & \multicolumn{2}{|c|}{ "Result } & \multirow[b]{2}{*}{ Day } & \multirow[b]{2}{*}{$Y_{t}$} & \multicolumn{2}{|c|}{ Result } & \multirow[b]{2}{*}{ Day } & \multirow[b]{2}{*}{$Y_{t}$} & \multicolumn{2}{|c|}{ Result } \\
\hline & & $\hat{P}_{t}$ & $\hat{Y}_{t}$ & & & $\hat{P}_{t}$ & $\hat{Y}_{t}$ & & & $\hat{P}_{t}$ & $\hat{Y}_{t}$ & & & $\hat{P}_{t}$ & $\hat{Y}_{t}$ \\
\hline 1 & 20163 & -777 & 19214 & 6 & 18742 & -777 & 20164 & 11 & 19606 & -777 & 20443 & 16 & 20241 & -277 & 18724 \\
\hline 2 & 21097 & -277 & 19886 & 7 & 18844 & -777 & 17965 & 12 & 19987 & -277 & 19329 & 17 & 20987 & -277 & 19964 \\
\hline 3 & 21593 & -277 & 20820 & 8 & 19309 & -277 & 18567 & 13 & 18376 & -777 & 19210 & 18 & 18618 & -1000 & 19987 \\
\hline 4 & 20380 & -777 & 20816 & 9 & 20561 & -277 & 19032 & 14 & 18422 & -777 & 17599 & 19 & 19099 & -277 & 18341 \\
\hline 5 & 20941 & -277 & 20103 & 10 & 21220 & -277 & 20284 & 15 & 19001 & -277 & 18145 & & & & \\
\hline
\end{tabular}

Based on Table 3 and Table 4, the results of forecasting with the original data is shown in the following Fig. 2.

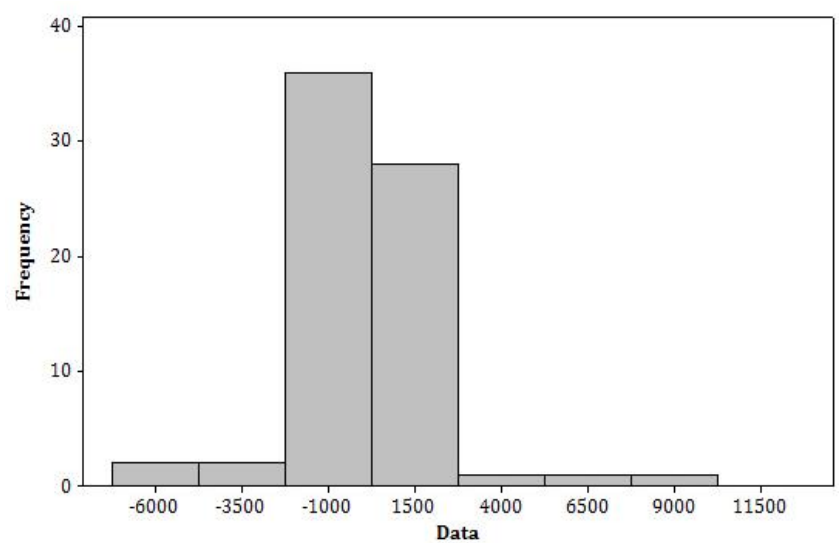

(a)

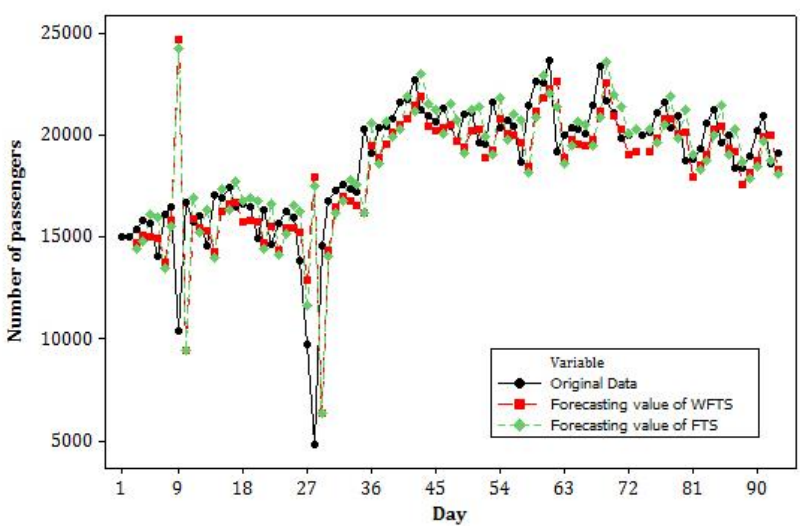

(b)

Fig. 2. (a) The chart of stationary data; (b) The plot of original data and forecasting result.

Here is a comparison of the value of MAPE and MSEfor the training data that is used to seethe results of forecastingusing the Fuzzy Time Series and Weighted Fuzzy Time Series Method.

Table 5. The Value of MAPE and MSE

\begin{tabular}{|c|c|c|c|c|c|}
\hline \multicolumn{3}{|c|}{ Fuzzy Time Series [11] } & \multicolumn{3}{|c|}{ "Weighted Fuzzy Time Series [16] } \\
\hline Training & $\begin{array}{l}\text { MAPE : } \\
13.98 \%\end{array}$ & $\begin{array}{l}\text { MSE : } \\
9078581.286\end{array}$ & Training & $\begin{array}{l}\text { MAPE : } \\
12.28 \%\end{array}$ & MSE : 8789055.686 \\
\hline Testing & $\begin{array}{l}\text { MAPE : } \\
5.90 \%\end{array}$ & $\begin{array}{l}\text { MSE: } \\
1798624.316\end{array}$ & Testing & MAPE : $4.89 \%$ & MSE : 1023784.947 \\
\hline
\end{tabular}

Table 5 show that MAPE and MSE values on the testing data has a lower value than the value of MAPE and MSE on the training data. It means that the forecasting model is acceptable to forecast the future. MAPE and MSE values with weighted fuzzy time series model is smaller than the value of MAPE and MSE with fuzzy time series. It means that forecasting Trans Jogja passengers with weighted fuzzy time series model is better than fuzzy time series model.

\section{Conclusion}

The result of the forecasting process with WFTS model is better than forecast with fuzzy time series model. Since, the values of MAPE and MSE with fuzzy time series model is bigger than the values of MAPE and MSE with weighted fuzzy time series model.However, this study did not consider the seasonal effect. In Indonesia, the effect of eid mubarokday makes the number of Trans Jogja passengers increase significantly. 
Therefore, it is expected that some future researchers concentrate on forecastingTrans Jogja's passengersin the seasonal moments.

\section{Acknowledgment}

The writer would like to thank Dishubkominfo DIY on their guidance for the work field,also for their cooperation and support data for the preparation of this paper.

\section{References}

[1] Badan, P. S. (2010). Resident Cencus 2010. Retrieved December 6, 2014, from http://sp2010.bps.go.id/index.php/site?id=3400000000\&wilayah=DI-Yogyakarta

[2] The Government Daerah Istimewa Yogyakarta. (2013). Profil Dinas Perhubungan, Komunikasi dan Informatika Daerah Istimewa Yogyakarta. Yogyakarta: Dishubkominfo DIY.

[3] Hidayat, S., Kencana, I., \& Jayanegara, K. (2013). Prediksi pengguna bus trans sarbagita dengan metode adaptive neuro fuzzy inference system. E-Jurnal Matematika, 2(3), 46-52.

[4] When-Xia, S., Ti, S., \& Hai, Z. (2009). Study on bus passenger capacity forecast based on regression analysis including time series. Proceedings of the ICTMTMA: Vol. 2. Measuring Technology and Mechatronics Automation (pp. 381-384), Hunan: IEEE.

[5] Song, Q., \& Chissom, B. S. (1993). Fuzzy time series and its models. Fuzzy Sets and System, 54, 269-277.

[6] Song, Q., \& Chissom, B. S. (1993). Forecasting enrollments with fuzzy time series-part I. Fuzzy Sets and System, 54, 1-9.

[7] Song, Q., \& Chissom, B. S. (1994). Forecasting enrollments with fuzzy time series-part II. Fuzzy Sets and System, 62, 1-8.

[8] Nurhayadi, S. A., \& Abadi, A. M. (2014). Fuzzy model optimation for time series data using a translation in the extent of mean error. Journal of Mathematics, 10(2), 267-274.

[9] Shah, M. (2007). Fuzzy time series: A realistic method to forecast gross domestic capital of India. ASC, 41, pp. 255-264.

[10] Abadi, A. M., Subanar, W., \& Saleh, S. (2009). Contructing fuzzy time series using combination of table lookup and singular value decomposition methods and its application to forecasting inflation rate. Journal Ilmu Dasar, 10(2), 190-198.

[11] Chen, S. M. (1996). Forecasting enrollments based on fuzzy time series. Fuzzy Sets and Systems, 81(3), 311-319.

[12] Yu, H.-K. (2005). Weighted fuzzy time series models for taiex forecasting. Phisica A: Statistical Mechanics and Its Applications, 349, 609-624.

[13] Lee, M. H. \& Suhartono. (2012). A weighted fuzzy time series for forecasting seasional data. Journal of Quality Measurement and Analysis, 8(1), 85-95.

[14] Suhartono, \& Lee, M. H. (2011). A hybrid approach based on winter's model and weighted fuzzy time series for forecasting trend and seasional data. Journal of Mathematics and Statistics, 7(3), 177-183.

[15] Suhatono, Lee, M. H., \& Javedani, H. (2011). A weighted fuzzy integrated time series for forecasting tourist arrivals. Journal of Informatics Engineering and Information Science, 252, 206-217.

[16] Lee, M. H. \& Suhartono. (2010). A novel weighted fuzzy time series model for forecasting seasonal data. presented at the $2^{\text {nd }}$ International Conference on Mathematical Sciences, Kuala Lumpur, Malaysia.

[17] Cheng, C. H., Chen, T. L., Teoh, H. J., \& Chiang, C. H. (2008). Fuzzy time series based on adaptive expectation model for TAIEX forecasting. Expert Systems with Applications, 34(2), 1126-1132.

[18] Dinas Perhubungan komunikasi dan inrofmatika DIY. (2014). Report 2012-2014. Yogyakarta: Trans Jogja sector. 
[19] Nason, G. P. (2006). Stationary and non-stationary time series. In H. Mader, \& S. C. Coles (Eds), Statistics in Volcanology, chapter 11. Geological Society of London.

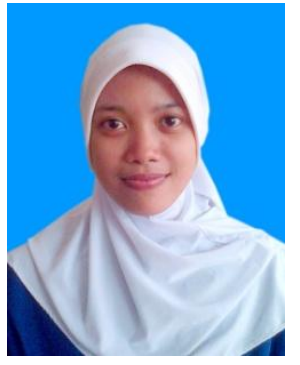

Kurrotul A'yun was born in Ponorogo, East Java, Indonesia, on October 29, 1992. She completed her education at the junior level Mts Al Mukarrom in 2008 and the senior secondary education MAN 2 Ponorogo. Now, she is studying Strata 1 level in Yogyakarta State University, and is listed as one of the students in Wahid Hasyim Islamic Boarding School in Yogyakarta. She is concentrating on mathematics in the Department of Mathematics, the Department of Mathematics Education, the Faculty of Mathematics and Natural Science, Yogyakarta State University.

She is actived in some areas of the organization. At the end of 2014, she completed her responsibility as the chairman of an Najah dormitory, one of dormitory in Wahid Hasyim Islamic Boarding School. In the first and the second year as a student, she is active in the Department Student Association (HIMATIKA) and was assigned as the head of education and reasoning in the second year. Now, she is registing as a mathematics teacher in senior high school of Wahid Hasyim. In addition, she also writes several papers. Papers that had been written is Optimize of forest of casuarina's tree management result (2014), etc.

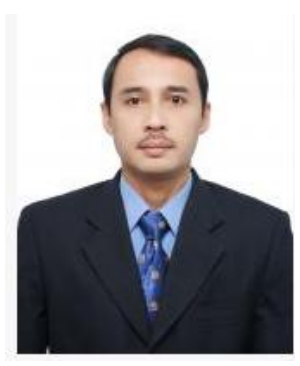

Agus Maman Abadi was born in Gunungkidul, Yogyakarta, Indonesia on August 28, 1970. He graduated the bachelor from Gadjah Mada University in 1994, and the master from Gadjah Mada University in 1998, and the Ph.D from Gadjah Mada University in 2010. He is a lecturer and a chief at Mathematics Department, Mathematicsand Natural Science Faculty, Yogyakarta State University, Indonesia.

He is interested in applied algebra and fuzzy model. There are more than 40 titles of his researches about fuzzy model and its application. Several papers that had been written there are Fuzzy model translation for time series data in the extent of median error and its application (applied mathematical sciences), Fuzzy model optimization for time series data using a translation in the extent of mean error (Journal of Mathematics and Statistics), etc. He precentate several papers at international conference in Cina (2014), Turkey (2012), Singapore (2008) and several universities in Indonesia. He got award from head of Yogyakarta University as a performance lecture in 2012. Now, he concentrates to his reasearch about optimation of fuzzy model and its application to diagnose cancer.

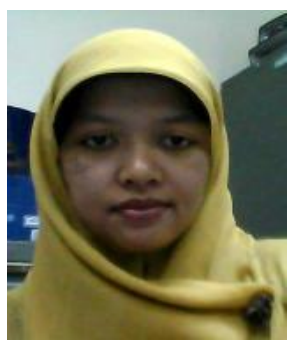

Fitriana Yuli Saptaningtyas was born in Gunungkidul, Yogyakarta, Indonesia on July 7, 1984. She graduated the bachelor from Mathematics Education Department of Yogyakarta State University in 2005 and graduated the master from Mathematics Department of ITS Surabaya in 2007. Now, she is a lecturer at Mathematics Department, Mathematics and Natural Science Faculty, Yogyakarta State University, Indonesia.

She is interested in applied and analysis mathematics. Several papers that had been written are about sediment transport of mathematics modelling using finite volume method in river channel junction (2007), scheduling using coloring graph (2008), lebesque space (2009), kalman filters otimation in water pollution (2011), applied floyd algorithm on Trans Jogja (2012), and applied ant algorithm (2013). Now, she concentrates to her reasearch about optimation genetics algorithm and fuzzy system. 